\title{
Construção Social de Gênero e Busca de Identidade em Persépolis
}

\author{
Construcción Social de Género y Búsqueda de Identidad en Persépolis \\ Social Construction of Gender and Identity in Persepolis
}

Mylena Fernanda Ribeiro ${ }^{1}$

\begin{abstract}
Resumo
Este texto mostra a necessida de reconhecer que qualquer tipo de repressão vivenciada hoje pelas mulheres, possui raízes patriarcais. Procurando ressaltar estas questões, faz-se uma retomada aos possíveis princípios da estigmatização carregada pela figura da mulher tanto no século XIX, quanto no atual e traz personagens mulheres da graphic novel que dialogam com a desconstrução que se procura no contemporâneo. A análise dessas personagens do quadrinho Persépolis, evidencia pontos importantes como suas histórias e trajetórias de vida, como cada uma lidou com situações em que foram confrontandas por serem mulheres. Esses posicionamentos debatem-se com pensamentos valiosos de teóricas importantes e estudiosas do "ser mulher" em socieade, tanto nos primórdios da luta pela importância da educação e a busca da existência da mulher como ser autônomo, quanto a assuntos envolvendo o assédio e feminicídio, discutidos atualmente. Estudar Persépolis e suas personagens contribui para a desmistificação do que se criou socialmente a respeito da "feminilidade" da mulher e do seu destino estar atrelado ao matrimônio; submissão e redução do seu "eu" para viver em sociedade.
\end{abstract}

Palavras-chave: gênero; identidade; mulheres; Persépolis; sociedade.

\section{Resumen}

Este texto muestra la necesidad de reconocer que cualquier tipo de represión vivenciada hoy por las mujeres, tiene raíces patriarcales. En la búsqueda de resaltar estas cuestiones, se hace una reanudación a los posibles principios de la estigmatización cargada por la figura de la mujer tanto en el siglo XIX, como en el actual y trae personajes mujeres de la graphic novel que dialogan con la deconstrucción que se busca en el contemporáneo. El análisis de estos personajes del cómic Persépolis, evidencia puntos importantes como sus historias y trayectorias de vida, como cada una lidió con situaciones en que fueron confrontandas por ser mujeres. Estas posiciones se debaten con pensamientos valiosos de teóricas importantes y estudiosas del "ser mujer" en sociedad, tanto en los primordios de la lucha por la importancia de la educación y la búsqueda de la existencia de la mujer como ser autónomo, en cuanto a asuntos involucrando el acoso y el feminicidio, discutidos actualmente. Estudiar Persépolis y sus personajes contribuye a la desmistificación de lo que se creó socialmente respecto a la "feminidad" de la mujer y de su destino estar atado al matrimonio; sumisión y reducción de su "yo" para vivir en sociedad.

Palabras claves: género; la identidad; la sociedad; las mujeres; Persépolis.

\begin{abstract}
This text shows the need to recognize that any type of repression experienced today by women has patriarchal roots. Trying to emphasize these questions, one makes a return to the possible principles of the stigmatization charged by the figure of the woman in the nineteenth century, as in the current and brings female characters from the graphic novel that dialogue with the deconstruction that is sought in the contemporary. The analysis of these characters in the Persepolis comic, highlighting important points such as their stories and life trajectories, how each dealt with situations in which they were confronted by being women. These positions are debated with valuable thoughts from important theoreticians and scholars of "being woman" in society, both in the early days of the struggle for the importance of education and the search for the existence of women as autonomous, as well as issues involving harassment and femicide, currently discussed. Studying Persepolis and their characters contributes to the demystification of what has been created socially about the woman's "femininity" and her destiny to be linked to marriage; submission and reduction of their "self" to live in society.
\end{abstract}

\footnotetext{
${ }^{1}$ Mestranda pelo programa de Pós-Graduação em Letras na UEL; Licenciada em Letras pela UEPG; Londrina, PR, Brasil; hey-myh@hotmail.com.
} 
Keywords: gender; identity; Persepolis; society; women.

\section{Problematização da construção social de gênero}

Há séculos que a figura da mulher vem sendo estigmatizada e fadada a papéis secundários em que precisa submeter sua subjetividade ao poderio masculino. Poderio este que criou uma ideia de figura feminina homogênea, casamento e maternidade como fins obrigatórios na vida de uma mulher. Muitas dessas construções, percebe-se hoje, acontecem desde a infãncia. Em $O$ Segundo Sexo, Beauvoir problematiza essa questão, quando ao discutir sobre como a menina é criada, a autora conta o quanto a criação desta difere da do menino, isso fica evidente nessa passagem:

Assim, a passividade que caracterizará essencialmente a mulher 'feminina' é um traço que se desenvolve nela desde os primeiros anos. Mas é um erro pretender que se trata de um dado biológico: na verdade, é um destino que lhe é imposto por seus educadores e pela sociedade. A imensa possibilidade do menino está em que sua maneira de existir para outrem encoraja-o a por-se para si. (BEAUVOIR, 1967, p.21)

Percebe-se que, além da passividade não ser um "dado biológico", mas uma característica ensinada e aprendida pela mulher desde a sua infância, o próprio novo "mundo de possibilidades" que é apresentado ao menino é algo que ele aprende existir somente para o seu sexo. Tanto o fechamento ou a abertura de possibilidades, são aprendidas, não são dados irrefutáveis e ambos podem iniciar na infância:

Às meninas, a cor símbolo da "feminilidade" é regra, o rosa está em grande parte das roupas que usam e dos brinquedos que ganham, brinquedos estes usualmente ligados aos afazeres domésticos que lembram uma cozinha ou uma casa, a preparam para aquilo que ela mais cedo ou mais tarde estará repetindo sem saber ao certo o que significa. Nisso retoma-se novamente Beauvoir, quando a autora delimita a diferença clara da espera pelo casamento por um homem, para a expectativa e espera de casamento para uma mulher em: "De uma maneira mais ou menos velada, sua juventude consome-se na espera. Ela aguarda o Homem. Sem dúvida, o adolescente também sonha com a mulher, deseja-a; mas ela será apenas um elemento de sua vida: não resume seu destino” (BEAUVOIR, 1967, p.66).

Em formatos geralmente sutis as construções de gênero começaram na sociedade, parecendo inofensivas, porém mostraram-se perigosas para a formação subjetiva de uma pessoa. Sem prestar muita atenção no significado a sociedade foi propagando tais atitudes que 
acabaram mantendo a vigência do patriarcado que, muito mais que destinar a cor das roupas das mulheres, quer controlar seus corpos, seus desejos, sua individualidade.

Para ser esposa e mãe, a mulher abre mão da possibilidade de explorar o mundo e as infinitas possibilidades de conhecer a si mesma. Por vezes, não lhe deram o direito de estudar antes de tomar uma decisão tão importante como é o casamento e a maternidade, apenas disseram-na que este era seu destino, por ser mulher. Dessa forma é que lhe foi negado um dos direitos mais reivindicados pelas mulheres no século XIX, o direito ao estudo.

Um dos fundamentos que firmaram o início da luta por direitos das mulheres foi a necessidade de educação para que a mulher pudesse dar passos para uma formação intelectual. Para muitas autoras esta é uma questão chave da luta feminista. A brasileira Ercília Nogueira Cobra foi voraz em defender que a mulher não precisava de caridade:

A mulher precisa de justiça, de equidade e educação. Deem-lhe isto, e podem depois deixá-la sozinha no mundo, que ela saberá defender-se e, se tiver filhos, cuidará deles muito melhor do que atualmente sob o odioso regime vigente no qual o homem dá uma magra proteção em troca de desgostos e humilhações incontáveis. (COBRA, 1924, p. 64)

Beauvoir também foi grande defensora do trabalho. Esse pensamento é evocado em várias passagens, dentre elas na declaração de que: "Foi pelo trabalho que a mulher cobriu em grande parte a distância que a separava do homem; só o trabalho pode assegurar-lhe uma liberdade concreta." (BEAUVOIR, 1967, p.447) Reafirma-se assim, a importância do suporte financeiro para a mulher, mais do que isso, a importância de prover-se a si mesma, pois isso, como pontua a autora, é uma forma de liberdade.

Apesar de não se estar mais no século XIX, vive-se com base em conceitos que foram herdados do passado. Hoje podem ser celebradas conquistas alcançadas com o avançar dos anos, contudo, não se pode deixar de pensar que há uma liberdade disfarçada, pois ainda há violência contra a mulher. Insiste-se em tentar delimitar que roupas as mulheres devem usar e se têm o direito de se sentirem ofendidas por algum tipo de insulto e abuso que possam ter sofrido. É a partir de um exame da sua conduta baseada na sua vestimenta e reputação que ela será julgada se foi vítima ou não.

Hoje se sabe que existem múltiplas maneiras de "ser mulher" na sociedade e estas maneiras podem ou não estar atreladas ao casamento e à maternidade, contudo, ainda muitas esferas da sociedade insistem em perpetuar essas ideias em discursos de teor machista que objetificam a figura da mulher e fadam-na, novamente, à subserviência masculina. É por esse 
motivo que se faz necessário dialogar sobre essas questões, estudar mais a fundo a gênese dessas construções de gênero e apresentar figuras/personagens que contribuam para a desconstrução dessa visão homogênea da figura da mulher. É com esse intuito que o quadrinho Persépolis foi escolhido como objeto de análise desse trabalho, por conter uma história marcante e ser vastíssimo em novas interpretações.

\section{Contextualizações necessárias}

Marjane inicia a narrativa com o ano de 1980, ano este marcado por algumas mudanças significativas no país, dentre elas a instituição do uso obrigatório do véu, mostrado pela personagem no começo da narrativa. Tudo aquilo que poderia lembrar o Ocidente e a modernização advinda deste, era banido, como forma de voltar-se ao Corão e formar um governo verdadeiramente islâmico. A figura 1 mostra um momento que deixa bem claro como eles planejavam tornar o Irã menos "ocidentalizado" e mais voltado às suas raizes, uma das medidas tomadas foi o fechamento das escolas bilíngues:
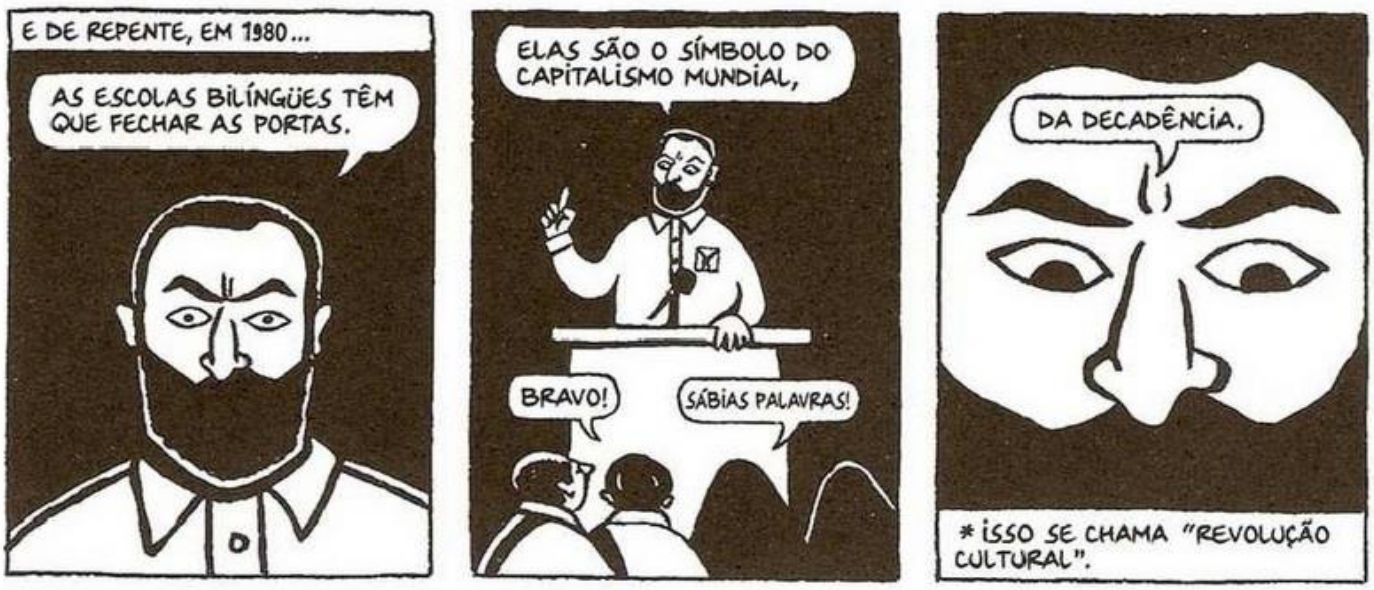

Figura. 1 - Fechamento das escolas bilíngues.

Fonte: SATRAPI, Marjane. Persépolis. Tradução: Paulo Werneck - São Paulo: Companhia das Letras, $2007^{2}$.

O Corão é um elemento importante para se entender a religião Islãmica, pois tem para os muçulmanos um valor particular, para eles é a própria palavra de Deus revelada ao profeta Maomé, confirmando e superando a própria Bíblia, praticamente um "Novo Testamento" (ELIADE, 1999, p. 193-194). Dentre suas premissas está a adoração única e exclusiva a Deus, o criador do universo, não devendo tomar outros por senhores ou soberanos a Deus; "a submissão e auto-rendição são práticas importantes para encontrá-Lo" (MAHMUD, 1978, p. 19), assim também como a realização de preces diárias.

\footnotetext{
${ }^{2}$ Por Persépolis não conter marcação numérica de páginas, resolvemos manter como está no original. Dessa forma, as marcações númericas precisas não aparecerão ao longo do texto, apenas a referência simples à obra.
} 
A instituição de medidas mais rígidas pelo governo adveio da revolução vivenciada pelo Irã no ano de 1979, responsável pela instauração da República Islâmica do Irã. Antes do acontecimento dessa grande revolução, o Irã vivenciou momentos significativos com dois grandes nomes da época: Reza Khan e Reza Pahlevi. O primeiro chegou ao poder por cooperar com os interesses dos ingleses, interesses estes ligados ao petróleo e à sua monopolização; Reza, então, precisava mediar tanto os interesses dos ingleses, quanto os interesses internos no petróleo. Esta situação é ilustrada pela autora no quadrinho. A figura 2 mostra o momento em que o pai de Marji está contando a história do Irã para ela ainda pequena:
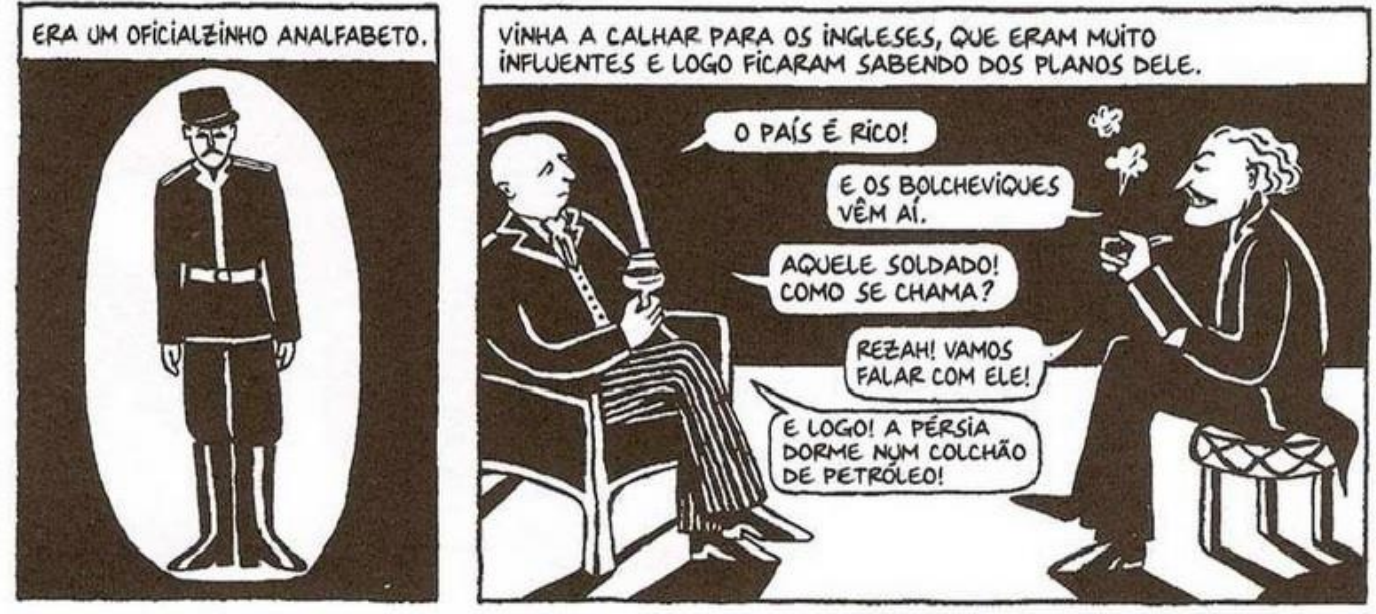

Figura. 2 - Ingleses escolhem Reza Khan visando seus próprios interesses no petróleo.

Fonte: SATRAPI, Marjane. Persépolis. Tradução: Paulo Werneck - São Paulo: Companhia das Letras, 2007.

Neste governo ainda houve uma abertura significativa com relação à saude e educação, e uma tentativa de modernização dos costumes iranianos. Foi neste momento que a liberdade com relação ao uso do véu ocorreu, acarretando algumas dissonâncias por parte de algumas mulheres que preferiram não sair de casa sem usá-lo. Contudo, essas reformas foram interrompidas por questões políticas e devido à Segunda Guerra Mundial, os ingleses acabaram forçando o general Reza a renunciar o governo e colocar seu filho no poder.

Reza Pahlevi, pelas suas fortes influências ocidentais, influências que favoreciam a assertiva de não rompimento com as potências européias, também promoveu mudanças nos setores de saúde e educação. Com relação às mulheres, em 1963 veio o direito ao voto. No entanto, grande parte da população se opôs a sua forma de governar. Os gastos excessivos, enquanto parte da população vivia na pobreza, o uso desmedido de força e violência geraram revolta na população. As agitações nacionais tomaram proporções maiores e em fevereiro de 1979, Pahlevi teve de sair do país: 


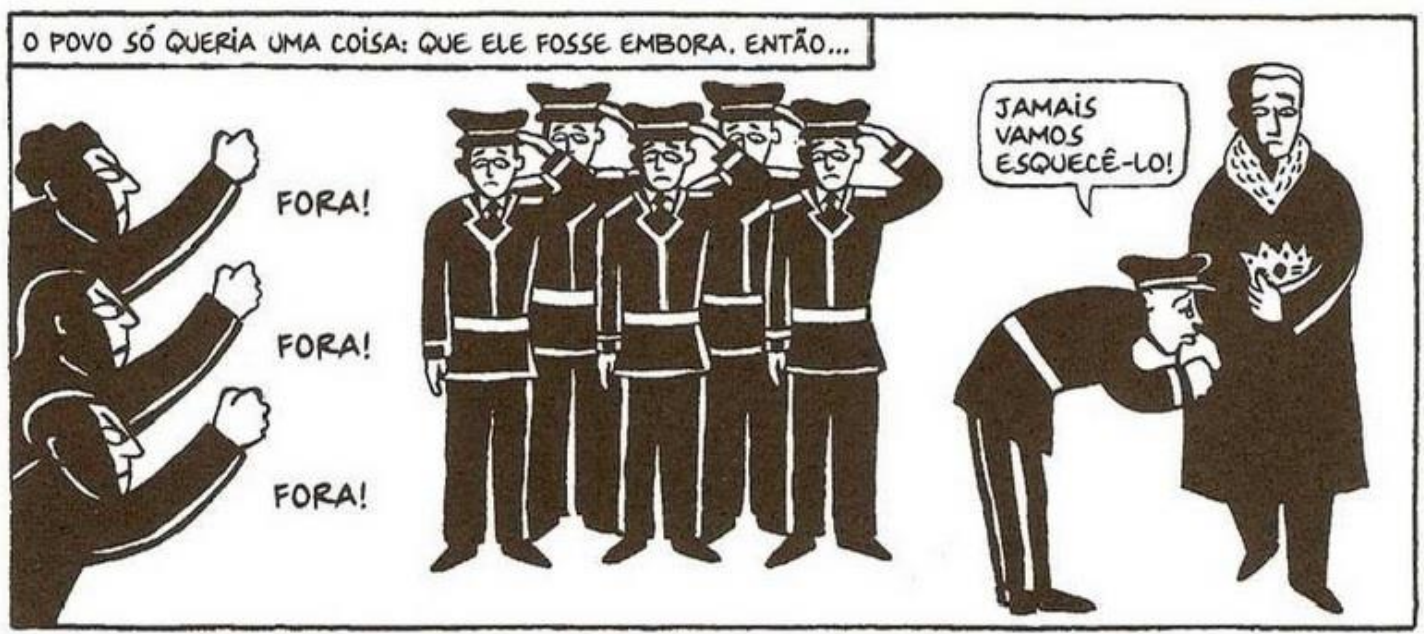

Figura. 3 - Saída forçada de Reza Pahlevi após grande movimentação da população.

Fonte: SATRAPI, Marjane. Persépolis. Tradução: Paulo Werneck - São Paulo: Companhia das Letras, 2007.

O xá foi substituído por Khomeini, este fortemente apoiado por fundamentalistas que logo mudaram todo o governo com o intuito de retornar aos preceitos religiosos e culturais do passado. O governo de Khomeini, que durou até a sua morte, em 1989, teve a constituição mudada com base no Corão e a maioria dos governantes que faziam a intepretação do livro eram homens e acabaram não dando aberturas para melhorar a condição da mulher.

Ao mudarem-se as leis e a forma de governo estritamente baseado no Corão, religião e política tornaram-se indissociáveis no Irã, como aponta o Livro Verde de Khomeini (1980, citado em NEUMANN, 2006): "a lei corânica, que não é senão a lei divina, constitui a base de todo o governo islâmico e reina infalivelmente sobre todos os indivíduos que dele fazem parte. (...) no Islã governar significa unicamente pôr em prática as leis do Corão”. Depois disso, muita coisa mudou no Irã.

\section{As personagens e suas identidades}

\subsection{Marjane:}

Ao abrir-se a primeira página do quadrinho, depara-se com a figura de Marji criança, nos seus dez anos de idade, contando como a história das mulheres naquele ano de 1980 mudaria para sempre com a obrigatoriedade do uso do véu. Passando pela Revolução de 1979, um ano antes, ela vivenciou a ausência dessa obrigação e também pode dividir o ambiente escolar com todos os seus amigos, independentemente do gênero.

É possível acompanhar a história e perceber que, quando menina, esteve vestida de revolucionária e brincando com outras crianças na rua. Em casa, recebia livros para que 
estudasse e entendesse mais sobre as revoluções e os revolucionários de seu país. Ainda no começo do quadrinho, um conflito ideológico aparece em algo que a escola ensinou para as crianças e o que os seus pais vão ensiná-la. A professora dissera às crianças que o Rei havia sido escolhido por uma figura divina, e é seu pai que explica a ela que, na verdade, ele não havia sido escolhido, nem suas atitudes eram divinas; mas, isso era algo dito quase que convencionalmente e muitas das atitudes tomadas por governantes diante de revoluções eram forçadas a serem vistas como divinas.

Nesse primeiro momento, já é possível retomar ao que foi preconizado por Beauvoir referente à menina. A passividade feminina é algo que a sociedade constrói na menina desde criança, inibindo sua sexualidade. Seus brinquedos são diferentes dos meninos, os elogios são sobre seu comportamento e beleza e não sobre seu intelecto; colocam-na como ser passivo e que pode ter sua subjetividade construída com base na opinião dos que a cercam.

É perceptível o contraponto que a infância de Marjane é, e também o quão estimulante e benéfica essa forma de criação pode ser na vida de uma pessoa adulta. Pensando essa questão juntamente com o que Simone de Beauvoir pontuou na segunda parte d'O Segundo Sexo, pode-se pensar mais profundamente como a criação de uma pessoa, aqui pensando a mulher, pode influenciar todas as áreas da sua vida:

\begin{abstract}
Ao contrário, na mulher há, no início, um conflito entre sua existência autônoma e seu 'ser-outro'; ensinam-lhe que para agradar é preciso procurar agradar, fazer-se objeto; ela deve, portanto, renunciar à sua autonomia. Tratam-na como uma boneca viva e recusam-lhe a liberdade; fecha-se assim um círculo vicioso, pois quanto menos exercer sua liberdade para compreender, apreender e descobrir o mundo que a cerca, menos encontrará nele recursos, menos ousará afirmar-se como sujeito; se a encorajassem a isso, ela poderia manifestar a mesma exuberância viva, a mesma curiosidade, o mesmo espírito de iniciativa, a mesma ousadia que um menino. (BEAUVOIR, 1967, p.22)
\end{abstract}

Evidencia-se com essa passagem que a mulher sendo criada para ser "o outro" e como objeto figurativo, perde sua autonomia, sua liberdade de escolha e assim, conhece menos a si mesma e menos o mundo ao seu redor; se criada com a mesma liberdade e estímulo à criatividade e ousadia pessoal, apresentará a mesma capacidade que um menino possui de afirmação de si.

Outro ponto de destaque da personagem é o uso que faz de sua sexualidade. Como ela mesma conta na história: "Jovens casais que se mostravam em público corriam perigo" (SATRAPI, 2007). Por terem pais não tradicionalistas, Marjane e seu namorado podiam ficar juntos na casa um do outro, sem preocupações de precisarem apenas se encontrar em público ou escondidos. A atitude de seus pais é importante para sua formação como pessoa, pode-se 
pensar que ela descobriu o sexo de forma mais natural, espontânea, sem grandes pressões para que usasse sua sexualidade de uma determinada forma ou de outra. A própria personagem pode decidir o que percebia como melhor, ninguém tomou dela o poder de decisão.

Perceber, então, que uma personagem pensa por si mesma e decide o que quer fazer com sua sexualidade e definitivamente faz aquilo que quer, rompe com essa corrente que prende e destina a mulher a ser objeto e não o desejo. É Marjane mesma quem confirma esta reflexão feita a respeito de sua sexualidade. Em dada parte da narrativa, ao comentar com uma colega de classe da universidade que usava pílula contraceptiva, muito naturalmente comenta que é porque "transa com seu namorado" (SATRAPI, 2007). Ao elucidar tal frase, é confrontada por colegas conservadoras a respeito da "falta de decência" que isso significava:

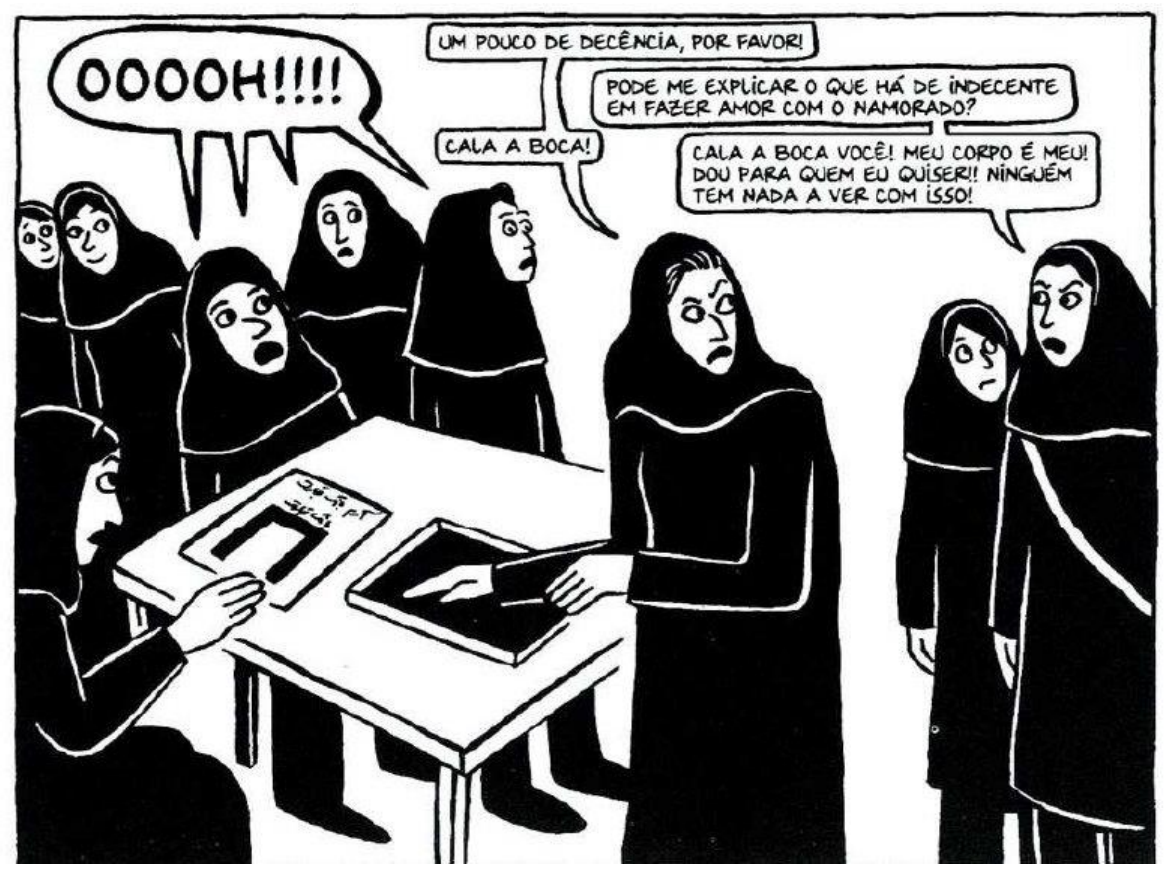

Figura. 4 - Posicionamento de Marjane quanto ao uso que faz do sexo e do seu corpo.

Fonte: SATRAPI, Marjane. Persépolis. Tradução: Paulo Werneck - São Paulo: Companhia das Letras, 2007.

O discurso contrário à visão conservadora da colega que a confronta é forte e cheio de verdade sobre si mesma. Marji é capaz de se afirmar frente a todos como mulher e como mulher desejante. Rompe-se assim, de certa forma, com um pensamento tradicionalista e opressor, que caminha juntamente com tantas opressões que as construções de gênero na sociedade perpetuaram.

\subsection{Taji Satrapi:}

A mãe de Marjane é outra figura de destaque do quadrinho, além de ser responsável por momentos em que marca a criação da protagonista, ela, como personagem na sua 
individualidade, é introduzida no quadrinho com características marcantes. É já nas primeiras páginas do quadrinho que Taji é apresentada em uma foto que fora publicada em um jornal e espalhada por toda a Europa: ela em uma manifestação contra o uso do véu. Por medo da repressão Taji pinta o cabelo e passa a usar óculos escuros por um bom tempo, para não ser reconhecida, pois isso certamente lhe traria consequências desastrosas. Percebe-se assim que a mãe de Marji toma atitudes de militância política.

Destacam-se mais dois momentos marcantes da personagem em que ficam claras, em seu comportamento e reação, algumas das reividicações que o movimento feminista faz. $\mathrm{O}$ primeiro deles é quando Marjane e seu pai vão encontrar Taji porque seu carro enguiçou e ela aparece correndo, chorando e diz o motivo:
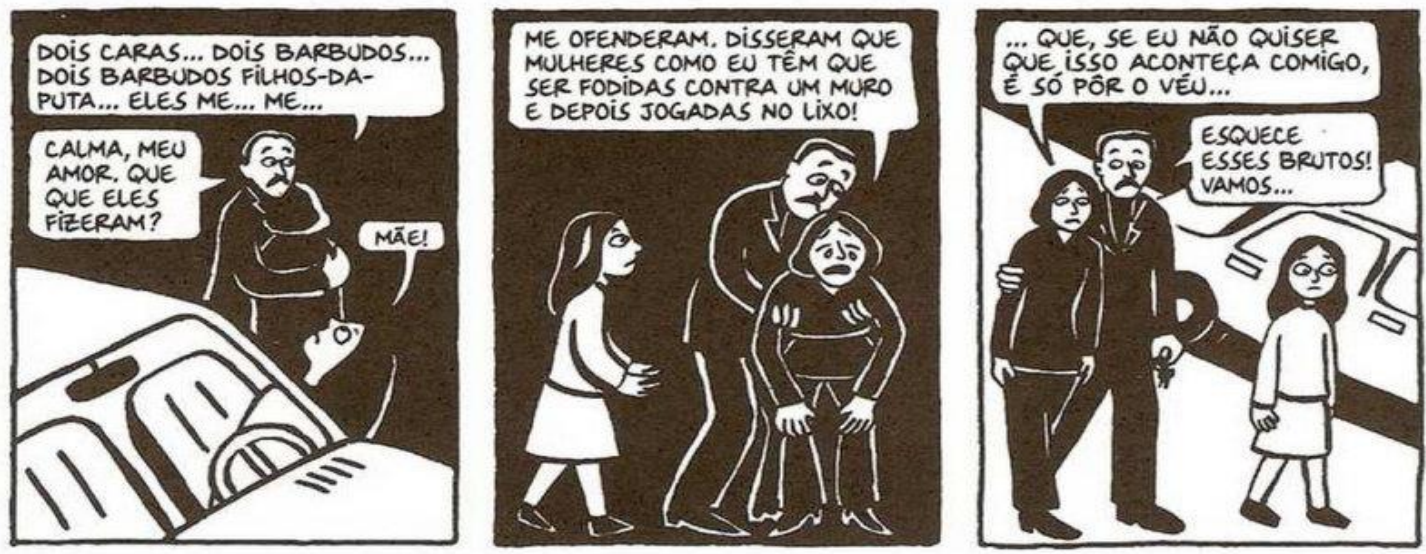

Figura. 5 - Taji conta sobre a violência que sofrera.

Fonte: SATRAPI, Marjane. Persépolis. Tradução: Paulo Werneck - São Paulo: Companhia das Letras, 2007.

Sabe-se que muitas das construções de gênero começam na infância, dessa forma, podese pensar que é na infância também que em momentos da vida são mostrados aos meninos que os homens são fortes e devem dominar as mulheres, como Marilyn French (1992) pontua no capítulo em que trata da "guerra pessoal dos homens contra as mulheres": "Desde a infância, os meninos são borbardeados com a mensagem de que os homens 'de verdade' dominam as mulheres, o que significa o controle do comportamento e a autorização para maltratá-las física e verbalmente.” (FRENCH, p. 219)

Ao retomar o que o quadrinho apresenta é possível perceber uma cena clara de violência contra a mulher. No contexto do quadrinho o motivo é a ausência do uso do véu, usado como justificativa para tal ato e mostram uma perpetuação de pensamentos que "autorizam" uma cultura de violência contra a mulher.

Pode-se pensar que a personagem da Taji mostra a realidade dessa cultura. Ela não é tratada como pessoa, mas como objeto que precisa obedecer a uma obrigatoriedade, uma 
autoridade que impôs o uso do véu. Para visualizar melhor a questão, coloca-se a imagem de que poderia ser qualquer outra mulher naquele contexto que o sujeito que agiu daquela forma com a Taji, agiria da mesma forma com outra mulher. Tal reflexão faz com que seja preciso voltar o olhar para a figura da mulher, pensando que a censura e violência são "autorizadas" contra todas mulheres. Taji nessa cena pode estar mostrando uma fatia de algo que todas as mulheres no mundo vivem.

Ao lembrar-se do Brasil, as mulheres não são obrigadas ao uso do véu como as iranianas e outras mulheres ao redor do mundo, contudo, o tamanho das roupas e o ambiente onde se encontram são, muitas vezes, usados como desculpa para justificar violência física e verbal. Assim, muitas mulheres crescem com o assédio ao redor delas, começando por vezes em casa, passando posteriormente ao assédio nas ruas que ainda é visto como um "elogio", tendo muitas vezes que enfrentar o assédio ainda no trabalho e nos relacionamentos amorosos. Ou seja, criou-se uma cultura em que esse tipo de atitude é comum e aceita em sociedade.

No que diz respeito ainda à violência contra a mulher, as vítimas podem se sentir compelidas a se calarem diante de alguma violência, muitas vezes por medo e vergonha. A sociedade, que tem suas bases fundadas na submissão feminina e na obediência da mulher, por vezes acaba culpabilizando a vítima, pelo uso que fez de sua roupa, o local que estava etc. French (1992) ressalta esse aspecto ao expor que as mulheres vítimas de violência são culpabilizadas pelas pessoas, sob a "alegação de que o merecem, por se exporem a riscos" (FRENCH, 1992, p 234). Volta-se à questão de que a vítima foi punida com violência, porque não fazia o uso do véu, ou de uma roupa "adequada".

Ainda destaca-se outro momento da personagem Taji no final do quadrinho. Marjane voltara para o Irã, iniciara seus estudos e decidira se casar. Após conversar com o marido a respeito, Taji decide apoiar a filha, no entanto, na cerimônia do casamento de Marjane, Taji chora ao abraçar a filha no banheiro. Eis o quadrinho em que conversam sobre o motivo de tal acontecimento: 

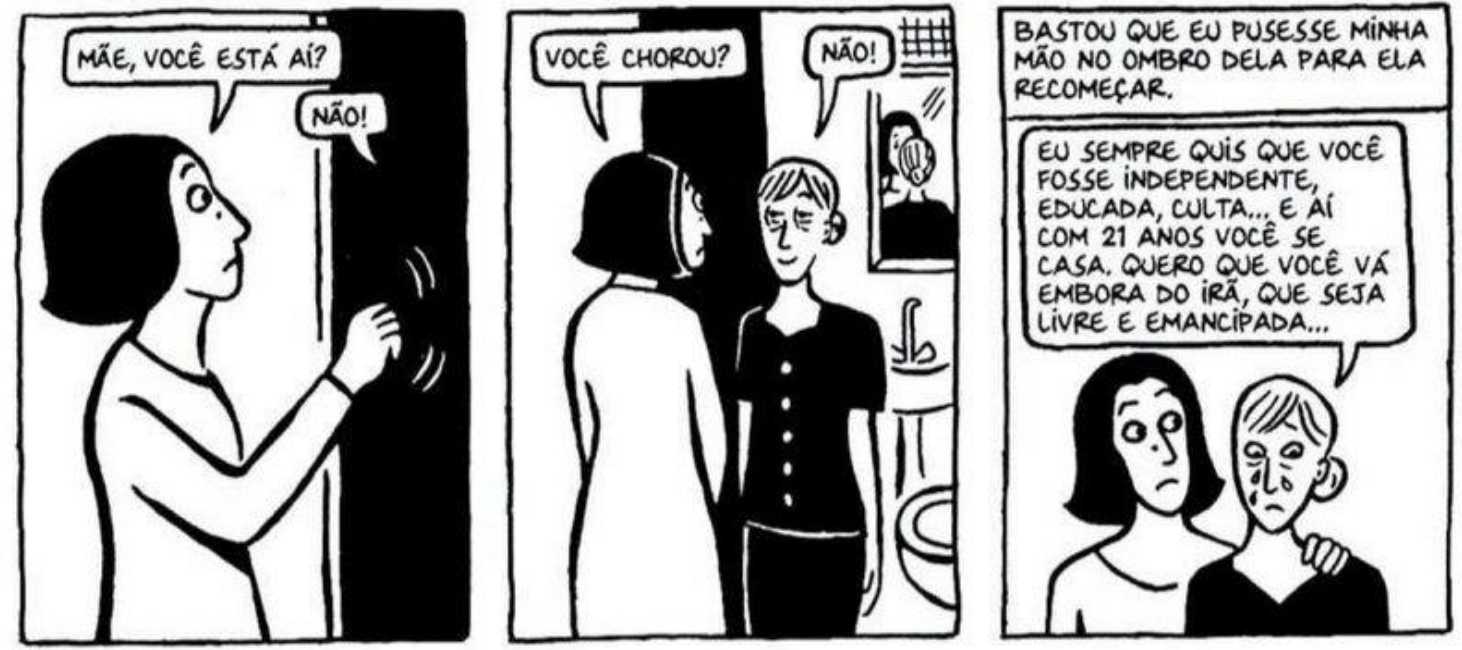

Figura 6 -Taji e Marjane no banheiro conversam sobre o casamento.

Fonte: SATRAPI, Marjane. Persépolis. Tradução: Paulo Werneck - São Paulo: Companhia das Letras, 2007.

Dentre tantas buscas que o movimento feminista fez desde seu início, a emancipação da mulher sempre se mostrou como pauta importante. Marjane conseguiu ser educada, mas sua mãe vê que o país em que vivem não dará a liberdade almejada à filha, quer, então, que ela vá embora para outro lugar. Nota-se, também, uma preocupação para com o casamento da filha, talvez por este ainda significar certa forma de dependência, ainda mais com as regras rígidas do Irã. Abre-se caminho para refletir que Taji não queria que Marjane casasse tão nova, mas que vivesse sua vida com liberdade.

A essa abertura reflexiva que a cena de Taji proporciona, pode-se somar a pensamentos de algumas autoras sobre o que poderia significar essa liberdade mencionada pela personagem. Para Woolf (1928) vê-se uma liberdade ligada a um ambiente para a mulher poder fazer ficção, a liberdade material, era algo importante: “a liberdade intelectual depende de coisas materiais. A poesia depende da liberdade intelectual” (WOOLF, 1928. p, 131).

Para que a mulher possa produzir criativamente, ela precisa ter condições financeiras para se manter. Beauvoir (1970) retoma essa ideia afirmando que: "independência material é uma das condições necessárias à liberdade interior” (BEAUVOIR, p, 137).

A mãe de Marjane, ao desejar à filha a liberdade e emancipação, pode estar renegando à Marjane o retorno ao lar como obrigação, ao conceito limitado de "feminilidade", mas desejando que ela avançasse na busca de sua "liberdade material e interior".

\section{Conclusão}

Este artigo foi escrito com o objetivo de analisar algumas personagens do quadrinho Persépolis, trazendo como base algumas teorias feministas que marcaram a história e assim, 
ressaltar pontos importantes dessas teorias como forma de desconstruir muito do que se foi criado em torno da mulher. Destacou-se a importância dada ao ínicio da luta por direitos da mulher, como para a educação e também para questões mais sensíveis, internas e de cunho existencial que foram entendidas pelas teóricas como necessárias para que a mulher conquistasse autonomia interna.

Ao colocar em evidência a personagem Marji foi possível perceber, a começar por sua infância, na escola, como a história do seu país não era contada de forma transparente e verdadeira às crianças, mas de forma maquiada. Marjane consegue ultrapassar muitas dessas barreiras por estar em uma família que valorizava sua formação intelectual e que buscava sua emancipação, como foi percebido na personagem de Taji Satrapi. Sua mãe, que queria a liberdade para a filha, ao invés da prisão que o casamento poderia significar. Este pensamento emancipatório foi algo que se buscou visualizar em conjunto com as teóricas e foi perceptível a urgência e o valor que grande parte delas deram a esta questão, evidenciando ainda mais a importância de Persépolis nesta discussão.

Com este trabalho, também, foi possível perceber que muitas das construções sociais de gênero estão ainda vigentes em nossa sociedade, apesar dos avanços que o movimento feminista tem feito. A violência perpetuada contra a mulher é visível e sabe-se essa violência tem raízes patriarcais.

Foi com o intuito de debater estas questões e instigar a criação de mais trabalhos e de mais discussões sobre a temática que este trabalho foi elaborado. Evidenciando a necessidade de continuar a discussão sobre a temática, como forma de desatar mais um pouco estes possíveis laços com o passado.

\section{Referências}

BEAUVOIR, Simone. O Segundo Sexo: A Experiência Vivida. Tradução de Sérgio Milliet. São Paulo: Difusão Européia do livro, 1967. Ed. $2^{a}$.

O Segundo Sexo: Fatos e Mitos. Tradução: Sérgio Milliet. São Paulo: Difusão Européia do Livro, 1970. Ed. $4^{\mathrm{a}}$.

COBRA, Ercília Nogueira. Virgindade Anti-higiênica: Preconceitos e convenções hipócritas. Ed. da Autora, São Paulo, 1924, 127 p.

ELIADE, Mircela, 1907-1986. Dicionário das religiões. Tradução: Ivone Castilho Benedetti. $-2^{\text {a }}$.ed. - São Paulo: Martins Fontes, 1999.

FRENCH, Marilyn. A Guerra Contra as Mulheres. Tradução: Maria Therezinha M. Cavallari. São Paulo: Best Seller, 1992. 
MAHMUD, Abdel Haleem. The Creed of Islam. Translated by Dr. Mahmud Abdel Haleem. World of Islam Festival Trust, 1978.

NEUMANN, M. N. Por detrás dos véus: A mulher muçulmana e as Revoluções Turca e Iraniana. Pap. Polít. Bogotá, Colombia, Vol. 11, No. 2, 761-795, 2006.

SATRAPI, Marjane. Bordados. Tradução: Paulo Werneck - São Paulo: Companhia das Letras, 2010.

Persépolis. Tradução: Paulo Werneck. São Paulo: Companhia das Letras, 2007.

WOOLF, Virginia. Um Teto Todo Seu. Tradução: Vera Ribeiro. São Paulo: Nova Fronteira S.A., 1928. 